\title{
Basis of high-pressure water-jet use for polymetallic nodule comminution
}

\section{Podstawy stosowania wysokociśnieniowej strugi wodnej do rozdrabniania konkrecji polimetalicznych}

\author{
PRZEMYSŁAW J. BORKOWSKI \\ JÓZEF A. BORKOWSKI \\ MICHAL BIELECKI \\ MARIUSZ O. JĘDRYSEK \\ TOMASZ ABRAMOWSKI *
}

Two-stage mechanical and hydro-jetting method of polymetallic nodules' comminution are presented in the paper. Physical basis as well as possibilities of high-pressure water jet method for efficient processing of such nodules, extracted from $4200 \mathrm{~m}$ below sea level, are given too.

KEYWORDS: polymetallic nodule, hydro-jet comminution, high-pressure water-jet

The resources of land minerals are depleted and it is necessary to look for such alternative mineral resources, that thanks to their content may be enough for humankind needs for many thousands of years. Therefore, at the end of the 20th century, intensive research for these minerals in the form of bottom sediments and subsurface deposits began. A clear increase in investment outlays in this area has recently led to the intensification of exploration and exploitation of the ocean depths. In developed countries, scientific research [8] has been intensified over mining systems of nodules, etc. Specialist enterprises have been established, producing and using appropriate devices $[3,6]$ and technological equipment [7].

Over thirty years ago Poland joined such activities, as part of its membership in the international organization InterOceanMetal. The management of this organization, based in Szczecin, has the seabed exploration area of 75,000 $\mathrm{km}^{2}$, located in the Clarion-Clipperton zone, which is located at the bottom of the Pacific, at a depth of $4,200 \div 5,200 \mathrm{~m}$, at a distance of about $1,600 \mathrm{~km}$ west of Mexico. This is one of the more promising areas in which about $10 \mathrm{~kg}$ of polymetallic nodules account for every square meter of the bottom surface. These nodules are usually slightly flattened bulbs with quite developed surface and a very high content of such metals as: manganese, cobalt, copper, iron and nickel. Estimated resources located in the said area amount to almost 450 million tons of metals, including almost 90 million tons of manganese, 4 million tons of nickel, 3.5 million tons of copper and approx. 0.5 million tons of cobalt [4]

\footnotetext{
* Prof. dr hab. inż. Przemysław Borkowski (przemyslaw.borkowski@pgi. gov.pl) - Państwowy Instytut Geologiczny PIG-PIB w Warszawie; prof. dr hab. inż. Józef A. Borkowski (jozef.borkowski@tu.koszalin.pl), dr inż. Michał Bielecki (michal.bielecki@tu.koszalin.pl) - Politechnika Koszalińska; prof. dr hab. inż. Mariusz O. Jędrysek (morion@jedrysek.eu) Uniwersytet Wrocławski; dr hab. inż. Tomasz Abramowski, prof. AMS (t.abramowski@am.szczecin.pl) - Akademia Morska w Szczecinie
}

In addition, six months ago, Poland purchased exploration licenses for 100 plots with a total area of $10,000 \mathrm{~km}^{2}$, located in the area of the so-called Central Atlantic rift, between West Africa and the east coast of Mexico, at a relatively small depth $-1200 \div 2400 \mathrm{~m}$. There are rich deposits of massive polymetallic sulfides containing rare earth metals and precious metals. Thanks to these undertakings, Poland joined an elite group of pioneers of undersea mining and geological exploration.

Taking into account the strategic situation and global technological achievements, the authors themselves have developed the basics of using a high-pressure water jet for submarine mining [1] and extracting [2] polymetallic nodules from the ocean floor.

However, to intensify the hydro-pneumatic vertical transport of nodules, it is necessary to fragment them in the bottom zone.

The purpose of this article is to discuss the physical foundations and possibilities of using a high-pressure water jet to crush polymetallic nodules.

\section{Attachments, apparatus and test conditions}

Polymetallic nodules extracted from the depth of about $4,200 \mathrm{~m}$ in the Clarion-Clipperton zone, are the subject of research of the international organization InterOceanMetal. The nodules were crushed in two phases - the jaw crusher was initially used to obtain a feed in the form of particles with a grain size of $0.5 \div 2 \mathrm{~mm}$, which in the constructed hydrodynamic mill were finally crushed using high-pressure water jet energy.

The main investigations of the effectiveness of the final hydrodynamic grinding of polymetallic nodules were carried out at the water pressure of 70, 100, 150 and $200 \mathrm{MPa}$. A water nozzle with a diameter of $2.7 \mathrm{~mm}$ and a crushinghomogenizing nozzle type RI2-1 with a diameter $\mathrm{dh}=2.4 \mathrm{~mm}$ were used. The distance of the homogenizing nozzle outlet from the grinding disk was $s=10 \mathrm{~mm}$.

Measurements of fineness of polymetallic nodules were carried out using the Analysette 22 MicroTec Plus laser particle size analyzer, allowing analysis and preparation of particle size distributions in the range of $0.08 \div 2000 \mu \mathrm{m}$.

The FEI Quanta 200 Mark II scanning microscope equipped with the EDAX Genesis XM 2i chemical analyzer was used to assess the shape and morphology of the crushed polymetallic nodules. 


\section{Hydro-jet crushing of concretions}

In the two-way method of grinding polymetallic nodules, their initial crushing was carried out in a jaw crusher with a yield of $8.49 \mathrm{~g} / \mathrm{sec}$. It provides: approx. $23.8 \%$ of the mass of particles with dimensions exceeding $1 \mathrm{~mm}$, approx. $18.1 \%$ of the mass of particles with dimensions of $0.7 \div 1 \mathrm{~mm}$, approx. $14.4 \%$ of the mass of particles with dimensions of $0.43 \div 0.7$ $\mathrm{mm}$ and approx. $43.7 \%$ of the mass of the finest particles - less than $0.43 \mathrm{~mm}$. All these particles (fig. 1) are an infusion for the hydro-jets mill, in which their final disintegration occurs due to the action of a high-pressure water jet. Typical distributions of nodules particles grinded in a hydro-jets mill, to which the Analysette 22 MicroTec Plus meter was used, is presented in fig. 2 . The increase in the pressure of the water stream favors a more intensive fragmentation of nodules and significantly increases the specific surface area of the particles obtained (fig. 3).
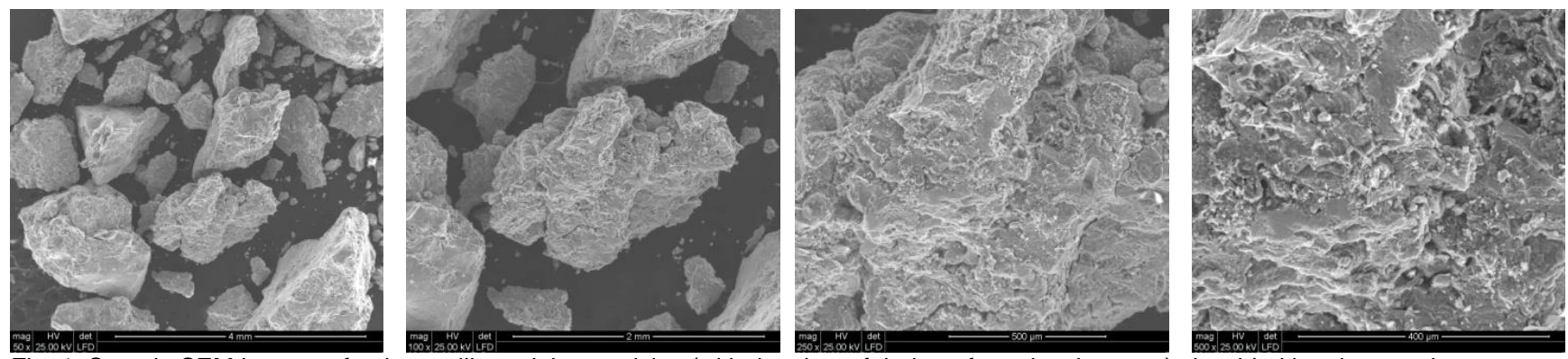

Fig. 1. Sample SEM images of polymetallic nodules particles (with the view of their surface development) shredded in a jaw crusher

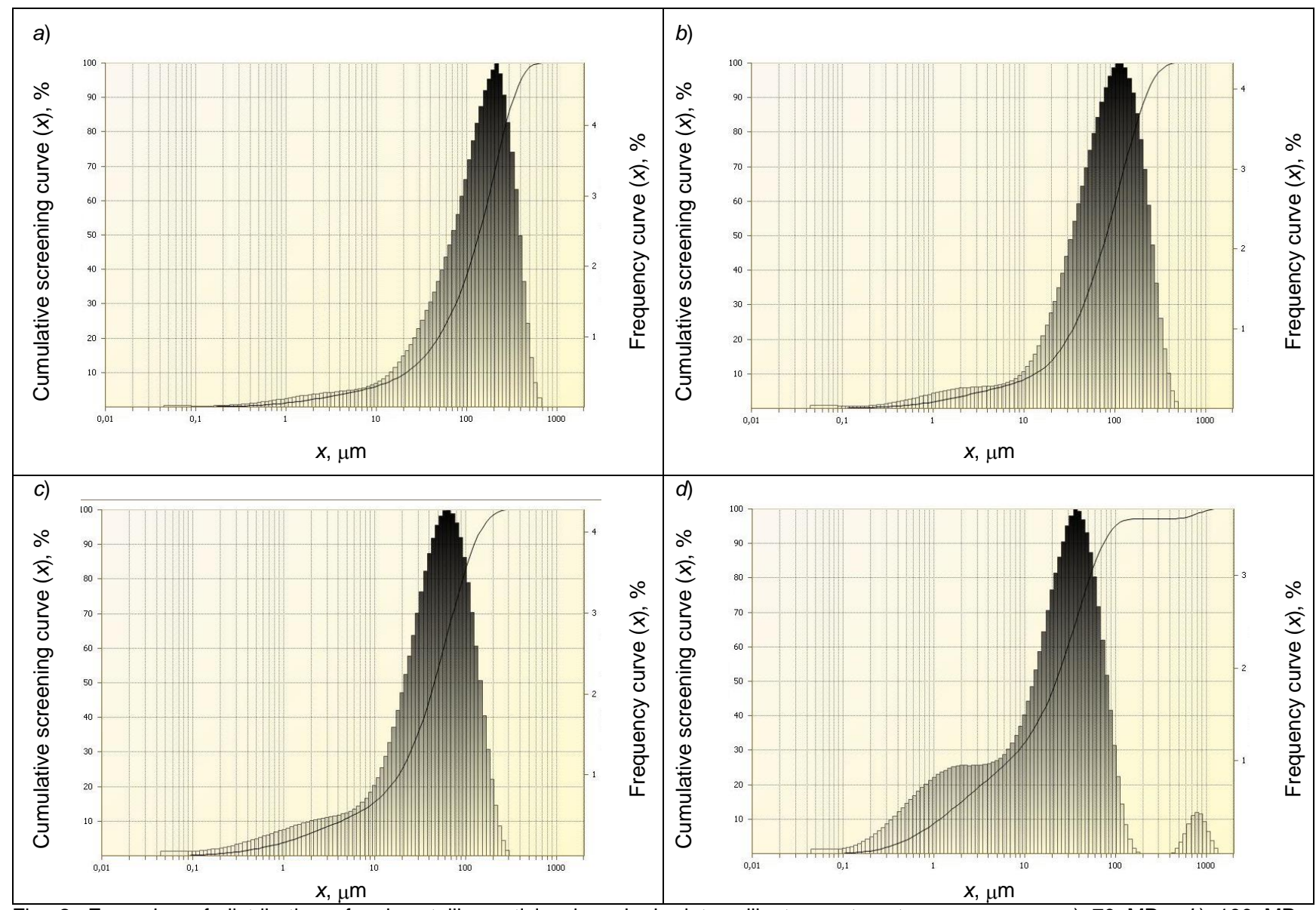

Fig. 2. Examples of distribution of polymetallic particles in a hydro-jets mill at a water stream pressure: a) $70 \mathrm{MPa}, b) 100 \mathrm{MPa}$, c) $150 \mathrm{MPa}$, d) $200 \mathrm{MPa}$


Fig. 3. Sample SEM images of polymetallic nodules ground in a hydro-jets mill at the pressure of a water stream: a) $70 \mathrm{MPa}, b) 100 \mathrm{MPa}, c)$ $150 \mathrm{MPa}$, d) $200 \mathrm{MPa}$ 
As results from the conducted research, as the pressure of the stream increases, the efficiency of grinding nodules increases (assessed on the basis of the reduction of the particle size obtained from hydro-jetting grinding) and the efficiency of the process (fig. 4).

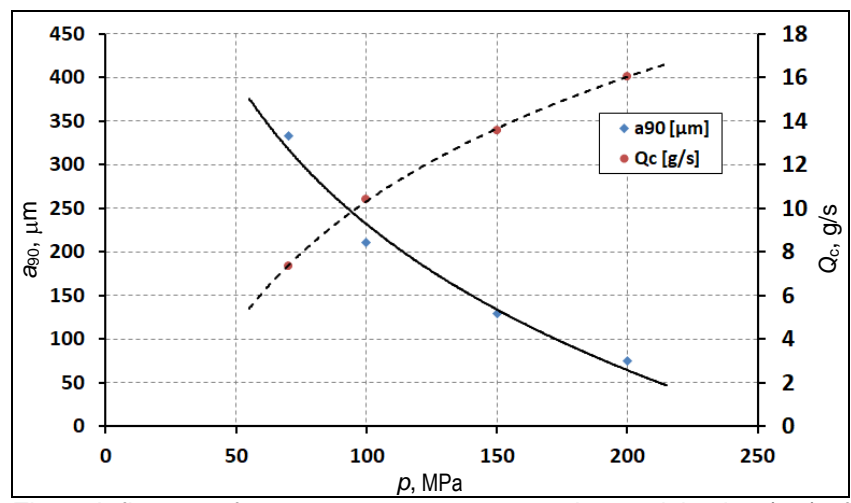

Fig. 4. Influence of water stream pressure on the particle size (a90) o finely divided concretions and efficiency $\left(Q_{c}\right)$ of their hydro-jets milling process
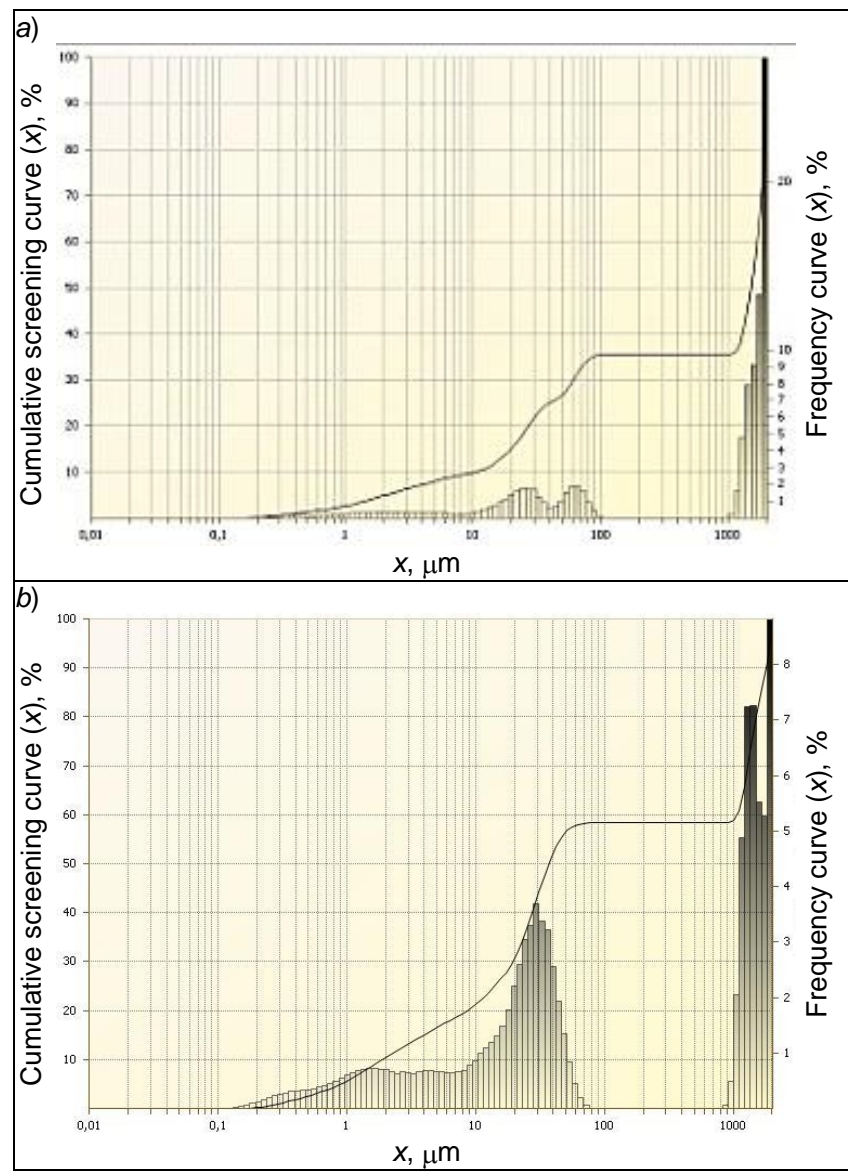

Fig. 5. Specific distributions of finely divided particles in a hydro-jets mill at a water jet pressure of $200 \mathrm{MPa}$

The production of such small particles of polymetallic nodules, crushed by the energy of a high-pressure water stream, also opens up a new perspective in terms of their more efficient hydro-pneumatic vertical transport. In such transport, the movement of the finest solid particles can be effectively supported by $\mathrm{CO}_{2}$ gas bubbles, which - as shown in earlier own research [2] - result from partial sublimation of dry ice granules of $\mathrm{CO}_{2}$ and reach the depth of the ocean floor from 1.7 to $2.1 \mathrm{~mm}$.

The relatively high quality and efficiency of the hydrodynamic nodules grinding process improves even more when the nominal water pressure increases. It usually also exceeds the efficiency of grinding them in a jaw crusher (8.49 $\mathrm{g} / \mathrm{s}$ ), which gives you much coarser particles.
However, one should signal the very important issue that at the largest pressures applied (200 MPa) in more than 20 cases particle distributions take on specific forms of multimodal waveforms - their typical examples are shown in fig. 5. This shows a tendency to segregate two, and sometimes even more the number of groups of particulate particles whose mechanical properties cause a clear differentiation of their erosive resistance. Initial recognition of the mechanism of this phenomenon is also supported by the results of chemical analyses [5]. This very important issue, affecting the possibility of pre-separation of materials obtained from polymetallic nodules, requires extensive specialist research.

\section{Energy consumption of the nodules grinding process}

An important feature of the process of shredding polymetallic nodules is energy use for its implementation. In order to determine its energy consumption, appropriate tests were carried out - their results for the hydrodynamic crumbling case are shown in fig. 6 .

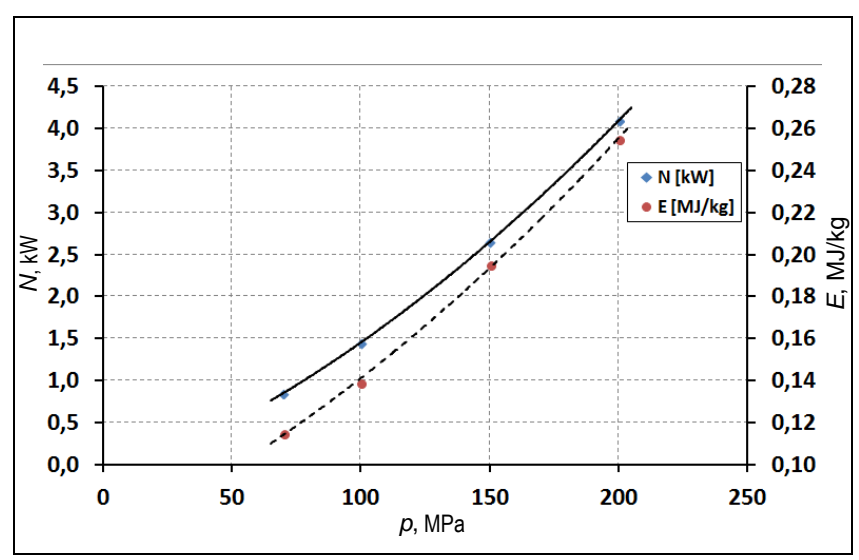

Fig. 6. Influence of water jet pressure on its power $(N)$ and unit energy $(E)$ of hydrodynamic fragmentation of nodules

These results indicate that the increase in water pressure increases the power of the water stream and causes an even more intensive increase in the unitary energy of grinding polymetallic concretions. This hydro-fluidic shredding generally has a much higher yield compared to mechanical grinding. Nevertheless, the occurring values of the hydrodynamic shredding unit energy significantly exceed the corresponding energy expended for crushing, e.g. in a jaw crusher $(E=0.04 \mathrm{MJ} / \mathrm{kg})$.

It would be advisable to combine both supporting methods to achieve a synergy effect.

\section{Conclusions}

Detailed analysis of the research results made it possible to formulate the following conclusions:

- Increasing the pressure of a water jet has a beneficial effect on the efficiency of hydrodynamic grinding of polymetallic nodules and on the efficiency of the process of such grinding, while it is disadvantageous from the point of view of its energy consumption.

- A comparison of the efficiency of both polymetallic nodules grinding methods confirms that the hydrodynamic shredding performance is generally higher compared to mechanical shredding in a jaw crusher.

- When grinding polymetallic nodules in a hydrogenic mill, particles are usually formed with a fairly regular isometric shape. The most advantageous morphology is obtained with a water pressure of $150 \mathrm{MPa}$.

- The most favorable effects of grinding polymetallic nodules in a hydro-jets mill are obtained at a water pressure equal to $150 \mathrm{MPa}$. 
- The hydro-stream method, using a high-pressure water jet to crush polymetallic nodules, is very promising.

- The present design solution of the universal hydrodynamic mill used in the discussed studies is a development base for the construction of various types of derivative devices for mincing minerals in a deep sea environment.

- One of the most urgent construction tasks is the development of a synergistic system for the fragmentation of polymetallic nodules, which would combine the advantages of both assisting methods: mechanical and hydrodynamic grinding of materials.

- There is a need to develop such a system of impact of a high-pressure water jet, which would allow to intensify the process of grinding polymetallic nodules, and at the same time would allow for the initial segregation of components.

\section{REFERENCES}

1. Borkowski P., Borkowski J. "Basis of high-pressure water jet implementation for poly-metallic concretions output from the ocean's bottom". Annual Set the Environment Protection. 13 (2011): pp. 65-82.

2. Borkowski P., Borkowski J., Jędrysek M. „Podstawy stosowania wysokociśnieniowej strugi wodno-lodowej do wydobywania konkrecji polimetalicznych z dna oceanu". Mechanika. XXXIV, 89, 4 (2017): pp. 423-434.

3. Engelman H.E. "Vertical hydraulic lifting of large-size particles A contribution to marine mining". The $10^{\text {th }}$ Annual Offshore Technology Conf. 1978. OTC 3173.

4. Jędrysek M.O. "Deep-ocean exploration of metals ore deposits controlled by the international seabed authority: Selected aspects of the present state and possible mining". 21st WMC \& Expo 2008. London: Taylor \& Francis Group, 2008, ISBN 978-0-415-48667, pp. 325-328.

5. Mackových D., Lučivjanský P., Pramuka S. "Determination of matrix composition of polymetallic nodules on samples taken in the cruise IOM-2014, including REE and noble elements. Final Report'. InterOceanMetal Joint Organization. State Geological Institute of Dionyz Stur. Spišská Nová Ves, 2015.

6. Nautilus Minerals Niugini Ltd. Preliminary Economic Assessment of the Solwara Project, Bismarck Sea, PNG. Technical Report compiled under NI 43-101. AMC Project 317045. 2018, p. 273.

7. Saito T. I in. "Dimensionless flow characteristics on air lift pump". Journal of Jet Flow Engineering. 12, 3 (1991): pp. 36-48.

8. Tindcheng L., Jiling M., Sheng L., Chengliang X. "Simulative analysis for deep seabed mining lifting systems". International Symposium on New Applications of Water Jet Technology. Ishinomaki, Japan, 1999, Paper No. H-3, pp. 245-254.

Translation of scientific articles, their computer composition and publishing them on the website www.mechanik.media.pl by original articles in Polish is a task financed from the funds of the Ministry of Science and Higher Education designated for dissemination of science. 